\title{
THAT IS WHY WE ARE AMAZING: A SHORT SPEECH DELIVERED WHEN RECEIVING THE STUDENT OF THE YEAR AWARD - 2016
}

\section{Doychin Nikolov}

\author{
Clinic of Urology, St. Marina University Hospital, Varna
}

The organization of time is the process that is the key to each successful outcome - deeds are more important than just words. All deeds must be the result of a clear vision for positive change, useful to society through professional practice or social activities. The principle that in a discussion between two people there are two ideas to be exchanged for two better, broader and more important ideas is a key to all positive change.

Following this train of thought, medical education in Bulgaria is world-class and never stops developing. Through the application of new technologies and methods in the process of training and professional practice, Bulgaria prepares excellent future medical specialists as leaders and innovators at an international level. It is no accident that Medical University "Prof. Dr. Paraskev Stoyanov", Varna, Bulgaria is an increasingly attractive training center for more than 1,200 international students from 44 countries.

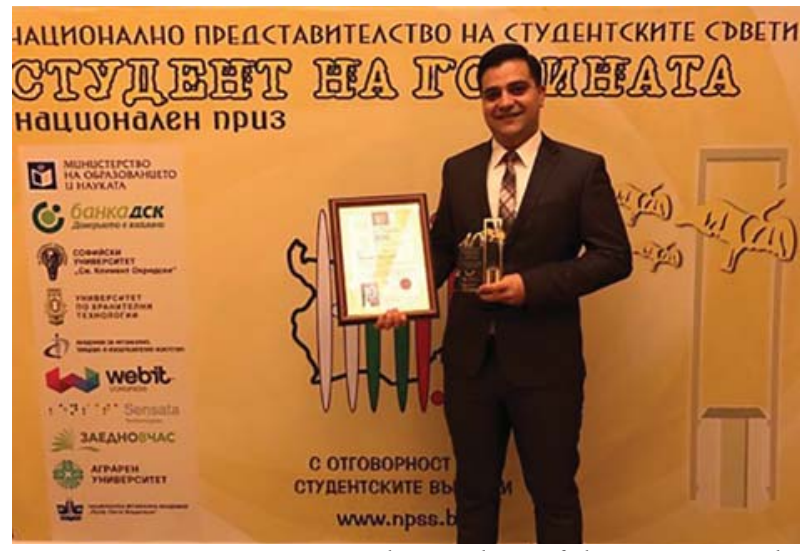

Figure 1. Upon receiving the Student of the Year Award $-2016$



Figure 2. 23 ${ }^{\text {rd }}$ of April 2016, South Beach, Varna, Bulgaria. Official Guinness Worlds Record for largest human DNA helix

The young people of Bulgaria can realize grandiose ideas. We have proven this and will continue to do so even more successfully and purposefully.

Activity from the student bench and desire to help the public are of great importance (Fig. 1). It is in regards to this that, once chosen, medicine is not only a future career, but also an initiative and obligation to contribute to the development of society sports events, charitable events, cultural events and more. An event combining all of these aspects is a Guinness World Record.

The desire of the students and staff of the Medical University "Prof. Dr. Paraskev Stoyanov “, Varna, Bulgaria was to create an event that could involve every citizen who welcomes innovation and believes in the future healthcare professionals. That is how the idea for a Guinness World Record for the largest human DNA helix came to be supported by 4,000 people who gathered on the South Beach in Varna on the $23^{\text {rd }}$ of April 2016 (Fig. 2) (1). "Be Part of the Future" was coined as the motto of the event, a message that young people with a fresh vision of tomorrow - the future of Bulgaria, accepted as their own.

The depicted double helix DNA chain and its associated multiple hydrogen bonds symbolized the genes of young people who can be united despite the differences between them. It was also not a coincidence that the hydrogen bonds were depicted in the colors of the Bulgarian flag - to demonstrate that the

Scripta Scientifica Vox Studentium, 2017;1(1):11-12 
Bulgarian spirit is alive in the hearts of young people and to remind them that only united together, we can achieve everything.

It was at high noon on the $23^{\text {rd }}$ of April 2016, when the Guinness World Records adjudicator Jack Brockbank, announced: "Medical University of Varna, people of Varna, you are officially amazing!" (Fig. 3) (1).

With this event, and the students of Medical University "Prof. Dr. Paraskev Stoyanov" proved primarily to themselves that as a society, having the faith in the medical profession, with unity despite differences, with ideas in the name of the public, everything is possible and that they are amazing (1)!

Success goes hand in hand with health, but also is important to build on what one has received during his school and university years, and to make the most of it later on. One must be committed to the learning process due to the responsibilities of the medical profession, but also never forget that one is primarily a person and for a single person to prosper society must prosper first.

\section{REFERENCES:}

1. Guinness World Records [internet] Largest human DNA helix. Available from: http://www. guinnessworldrecords.com/world-records/ largest-human-dna-helix

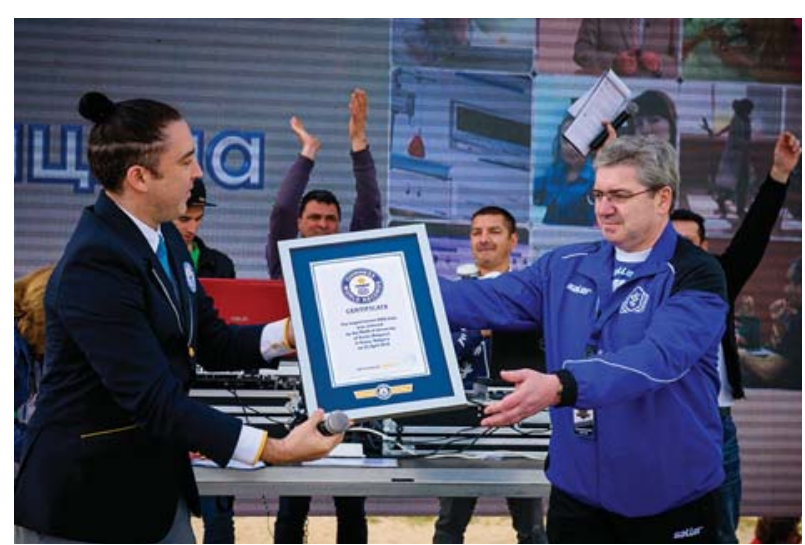

Figure 3. Guinness World Records adjudicator Jack Brockbank presenting the World Record Certificate to the Rector of Medical University "Prof. Dr. Paraskev Stoyanov", Prof. Krasimir Ivanov 